\title{
ENVIRONMENTAL BENEFITS OF IMPROVED WATER AND NITROGEN MANAGEMENT IN IRRIGATED SUGARCANE: A COMBINED CROP MODELLING AND LIFE CYCLE ASSESSMENT APPROACH ${ }^{\dagger}$
}

\author{
M. VAN DER LAAN ${ }^{1,2 *}$, A. JUMMAN ${ }^{1}$ AND S.R. PERRET ${ }^{3}$ \\ ${ }^{1}$ South African Sugarcane Research Institute, Mount Edgecombe \\ ${ }^{2}$ Department of Plant Production and Soil Science,University of Pretoria, Hatfield, Pretoria, South Africa \\ ${ }^{3}$ Centre de Coopération Internationale en Recherche Agronomique pour le Développement, UMR G-Eau, \\ Montpellier, France
}

\begin{abstract}
The application of irrigation water and nitrogen $(\mathrm{N})$ fertilizer in excess of crop demand reduces profitability and has multiple detrimental impacts on the environment. $\mathrm{N}$ dynamics in agroecosystems are extremely complex, and mechanistic crop models are most often required to quantify the impact of improved management practices on reducing fertilizer $\mathrm{N}$ losses. In this study, Life Cycle Assessment (LCA) methodology and mechanistic modelling was used to quantify the environmental benefits of improved management of water and fertilizer $\mathrm{N}$ by sugarcane farmers in a case study in Pongola, South Africa. A baseline scenario, representing farmer intuition-based irrigation scheduling management, and two additional scenarios in which water, and water and $\mathrm{N}$ were more rationally managed, were compared. Results show that improved water and $\mathrm{N}$ management can lead to a $20 \%$ reduction in non-renewable energy consumption per functional unit (FU), with sustained or even increased yields. Total GHG emissions can potentially be reduced by $25 \%$ through more efficient water and $\mathrm{N}$ management. Limiting the rates of fertilizer $\mathrm{N}$ applied, made possible by decreasing $\mathrm{N}$ leaching through improved irrigation scheduling, resulted in the highest reductions for both impact categories. While total water consumption was very similar between the scenarios, more efficient use of
\end{abstract}

\footnotetext{
† Bénéfices environnementaux de la gestion raisonnée de l'eau et de l'azote en canne à sucre irriguée : Approche combinée de modélisation de la culture et d'analyse du cycle de vie à Pongola, Afrique du Sud

* Correspondence to: M. van der Laan, Department of Plant Production and Soil Science, University of Pretoria, South Africa. E-mail: michael.vanderlaan@up.ac.za
} 
rainfall was achieved through accurate scheduling, reducing blue water requirements. Through the simultaneous consideration of multiple environmental impacts, combining mechanistic crop modelling and LCA shows potential to identify improved management practices as well as to establish environmental stewardship incentives.

KEY WORDS: acidification, DSSAT-Canegro, eutrophication, global warming potential, sucrose, water consumption

\section{RESUME}

L'application d'eau d'irrigation et d'engrais azotés $(\mathrm{N})$ en excès par rapport à la demande des cultures réduit la profitabilité et a de multiples impacts négatifs sur l'environnement. La dynamique de l'azote dans les agrosystèmes est extrèmement complexe, et des modèles de culture mécanistes sont souvent nécessaires pour quantifier l'impact de pratiques de gestion améliorées sur la réduction des pertes en azote. Cette étude utilise la méthodologie de l'Analyse du Cycle de Vie (ACV) combinée à la modélisation mécaniste pour quantifier les bénéfices environnementaux d'une gestion améliorée de l'eau et des fertilisants azotés par des producteurs de canne à sucre, dans une étude de cas à Pongola, Afrique du Sud. Un scénario de base représente les pratiques courantes et intuitives des producteurs en termes d'irrigation, et deux scénarios supplémentaires représentent des pratiques de gestion plus rationnelles de l'eau, et de l'eau et des engrais, respectivement. Les résultats montrent qu'une meilleure gestion de l'eau et de l'azote peut générer une réduction de $20 \%$ de la consommation en énergie non-renouvelable, avec des rendements maintenus voire améliorés. Les émissions totales de GES peuvent potentiellement être réduites de $25 \%$. La réduction des applications d'engrais, rendue possible par le moindre lessivage de l'azote sous irrigation raisonnée, résulte en de fortes réductions de ces deux catégories d'impacts. La consommation totale en eau est similaire entre scénario de base et scénarios de meilleure gestion de l'eau; cependant l'utilisation de l'eau de pluie est plus efficiente avec les irrigations raisonnées, réduisant ainsi les besoins d'extraction de la ressource. Par la prise en compte simultanée d'impacts environnementaux multiples, la combinaison de l'ACV et de la modélisation mécaniste de culture montre un potentiel pour identifier les pratiques améliorées et pour développer un accompagnement en éco-conception de systèmes.

MOTS CLÉS: acidification; DSSAT-Canegro; l'eutrophisation; le potentiel de réchauffement planétaire; le saccharose; la consommation d'eau 


\section{INTRODUCTION}

Intensive crop production can result in a range of negative environmental impacts, including climate change as a result of greenhouse gas (GHG) emissions, water and air pollution, and consumption of non-renewable resources. There is a growing trend in the use of Life Cycle Assessment (LCA) to quantify the full range of potential environmental impacts of agricultural products. LCAs have also been effectively applied to compare the environmental impacts of alternate on-farm management practices (Brentrup et al., 2001; Brentrup et al., 2004b; Mouron et al., 2006; Blengini and Busto, 2009), and are an effective instrument for monitoring for any 'pollution swapping' (Thorburn and Wilkinson, 2012) or 'problem shifting' (Finnveden et al., 2009).

High growth rates and dry matter production of sugarcane warrants the application of relatively large quantities of irrigation water and nitrogen $(\mathrm{N})$ fertilizer. Nonetheless, low water and $\mathrm{N}$ use efficiencies are often reported for this crop, and this can be attributed to poor farmer management practices in many cases. Water use efficiencies ranging widely from 7.4 to 16.9 tons cane per $100 \mathrm{~mm}$ of evapotranspiration (ET) and 0.5 to 1.9 tons sucrose per $100 \mathrm{~mm}$ of ET have been reported in the literature (Kingston, 1994; Inman-Bamber et al., 2000). Nitrogen use efficiencies around 50\% are commonly observed worldwide (Meyer and Wood, 1994; Wood et $a l ., 2010)$. Nitrogen fertilizer recommendations are usually not site-specific and crop uptake is affected by factors such as soil characteristics, cultural practices and the $\mathrm{N}$ fertilisers timing and application method. In Australia, Thorburn et al. (2011) observed that using the 'N replacement system', which aligns $\mathrm{N}$ applications with actual crop production, meant that average fertiliser applications can be reduced by $35 \%$ while still obtaining yields similar to those achieved with conventional fertilizer $\mathrm{N}$ management. $\mathrm{N}$ lost to the environment was estimated to be approximately 50\% lower using the replacement system. Generally, pressure to reduce water consumption and environmental pollution is increasing in most sugarcane regions (InmanBamber et al., 2000; Hurst et al., 2004; Thorburn et al., 2011).

In cropping systems there is often a very strong and complex interaction between water and N (Parashar et al., 1978; Ingram and Hilton, 1986; Widenfield, 1995). For example, reduced transpiration as a result of water stress has been observed to decrease $\mathrm{N}$ uptake. The high solubility of $\mathrm{NO}_{3}{ }^{-}$in most soils makes it susceptible to leaching; significant quantities of $\mathrm{N}$ can therefore be lost during periods of deep drainage potentially leading to $\mathrm{N}$-limited crop growth later in the season. Anaerobic soil conditions associated with saturated soils arising from poor irrigation water management, poor drainage, or a combination of these can lead to increased denitrification gaseous $\mathrm{N}$ losses. The application of irrigation water and fertilizer $\mathrm{N}$, 
especially in excess of crop demand, has an array of environmental impacts, including nonrenewable energy consumption, greenhouse gas emissions and air and water pollution. The adoption of objective irrigation scheduling remains low in South Africa and internationally (Cluverwell et al., 1999; Stevens et al., 2005; Annandale et al., 2011), and $\mathrm{N}$ fertilizer is often applied in excess of crop demand to maximise crop yields based on farmer perception of target yields which are often over-estimated (Thorburn et al., 2011).

South Africa is a water scarce country with irrigation using around $60 \%$ of total runoff water or just under $40 \%$ of exploitable runoff (Department of Water Affairs and Forestry (DWAF), 2004). This large proportional use of blue water has resulted in increasing pressure to transfer water to other sectors (Annandale et al., 2011). Sugarcane production occurs exclusively in the eastern parts of the country because of favourable soils and climate. Of the total area under cultivation, $25 \%$ is irrigated and predominantly located in the Crocodile River, Komati-Lomati River and Pongola River catchments. Emerging water quality problems have been observed for the rivers in these catchments (Van der Laan et al., 2012), and rising competition for water from domestic and industrial sectors, and pressure to increase international and environmental flow obligations means that irrigation has a key role to play in the sustainable use of water resources in these catchments.

LCA studies have been completed for sugarcane products in Australia (Reouf and Wegener, 2007), Mauritius (Ramjeawon, 2008), Cuba (Contreras et al., 2009), South Africa (Mashoko et al., 2010), and Brazil (Seabra et al., 2011). Seabra et al. (2000), Ramjeawon (2008) and Contreras et al. (2009) considered the environmental benefits of cane-derived products. Renouf et al. (2008) compared Australian sugarcane with United States corn and United Kingdom sugar beet as sources of bio-products, and Mashoko et al. (2010) conducted an LCA for the entire South African sugar industry (rainfed plus irrigated regions). Obligations to report the environmental burden of sugar production and potential environmental benefits of sugarcane by-products can be informed using LCAs. LCAs can also be used to provide information to farmers about the causes of environmental impacts and investigate the management influence on environmental impacts, allowing farmers to focus on particularly relevant impacts (Mouron et al., 2006). However, as LCA studies are often reliant on information from databases or published studies, comparing the influence of region-specific improved management practices is hampered.

Presented here are results from an LCA-mechanistic crop modelling framework to study and quantify the environmental benefits of improved irrigation and fertilizer $\mathrm{N}$ management in sugarcane produced under irrigation in Pongola, South Africa. Impact categories and classification/characterisation methodologies have been selected according to suitability for 
sugarcane production systems, and shortcomings and potential improvement to the framework are discussed.

\section{MATERIALS AND METHODS}

\section{Goal and scope definition}

The goal of this assessment is to develop a suitable LCA framework for sugarcane production and to apply it to quantify the environmental benefits of improved irrigation water and $\mathrm{N}$ fertilizer management. The analysis is based on data acquired during a combined lysimeter and field trial conducted in Pongola, South Africa $\left(27^{\circ} 24^{\prime} \mathrm{S}, 31^{\circ} 35^{\prime} \mathrm{E}, 308\right.$ masl; mean annual temperature $=21{ }^{\circ} \mathrm{C}$, mean annual rainfall $=690 \mathrm{~mm}$ ) from 1986-1989 (Thompson, 1991; Van der Laan et al., 2011). The system under investigation (Figure 1) is a virtual farm representing the mainstream features and practices in the Pongola area (farm size, cropping system, equipment and practices). Following calibration and validation, the DSSAT-Canegro model (Jones et al., 2003; Van der Laan et al., 2011) was used to simulate water use, crop yield and extractable sucrose content, and soil carbon and $\mathrm{N}$ dynamics over 16 seasons between 1986 and 2001 (two cycles of one plant crop followed by seven ratoon crops). The $1.8 \mathrm{~m}$ deep sandy clay soil classified as a high yield potential Hutton soil form (Soil Classification Working Group, 1991) [Ferric Luvisol (FAO)/Alfisol (USDA)] and is representative of around 23\% of soils in the irrigated regions of the South African sugar industry (South African Sugar Association Experiment Station (SASEX), 2000). Selected soil properties used for model initialization are presented in Table I. The farm was assumed to have a total area of 200 ha under pivot irrigation, with $90 \%$ of the area being harvested annually. Actual weather data over the 16 seasons were mobilized in modelling. The focus of the study is on sugarcane production and the impact of agronomic management practices, so capital goods (farm facilities and infrastructure, irrigation equipment, etc.), personnel, the manufacturing of machinery, transport to the mill and further processing of sugarcane at the mill level are considered beyond the scope of this study. The functional unit (FU) is a metric ton of extractable sucrose produced leaving the farm gate (in the form of fresh, recently burnt, sugarcane stems). Normalisation and weighting does not form part of this analysis, which provides only mid-point environmental impact indicators. 


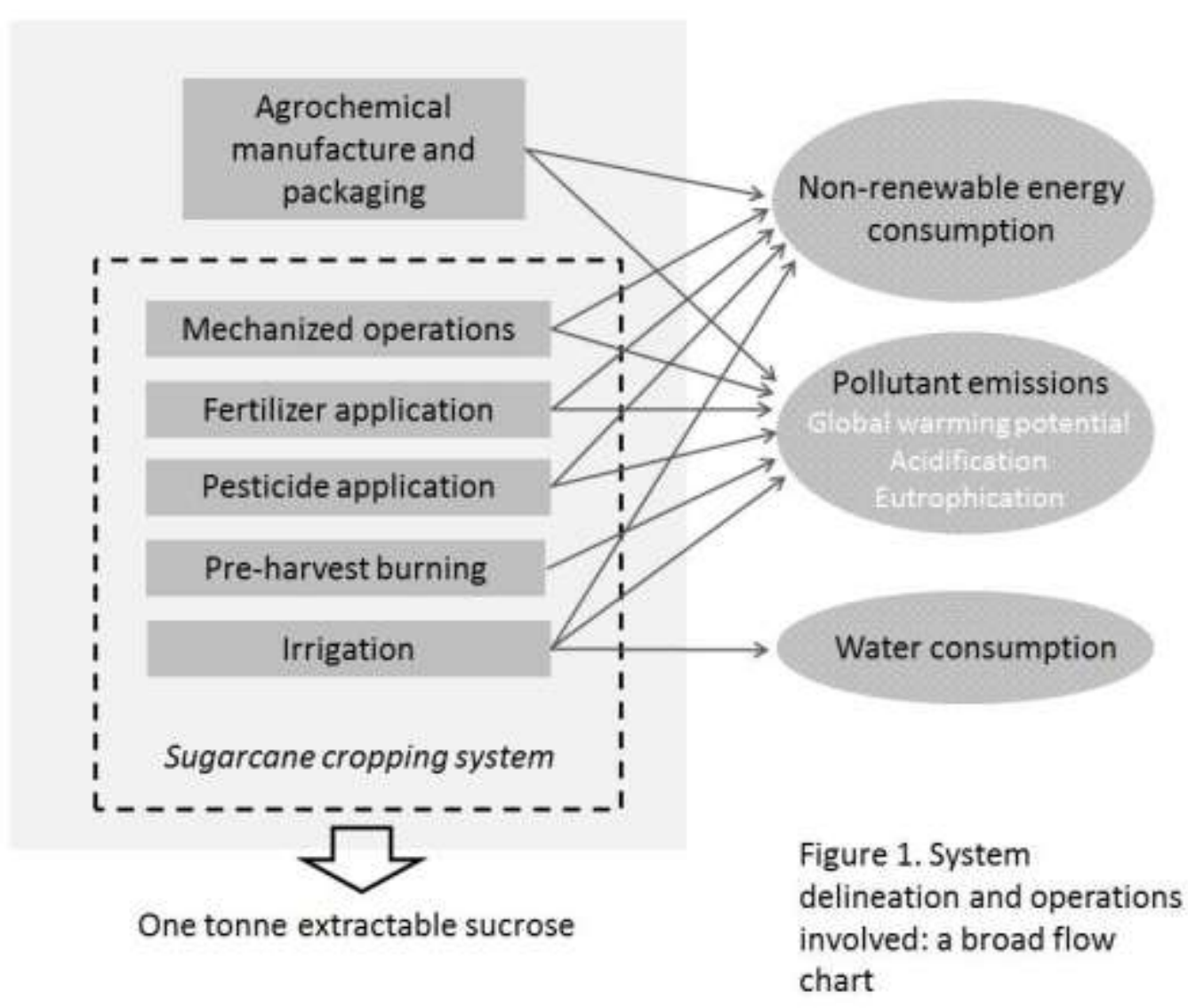

Table I. Selected soil properties for the simulated Hutton soil

\begin{tabular}{lccccccc}
\hline Depth $(\mathrm{cm})$ & $\mathrm{pH}\left(\mathrm{H}_{2} \mathrm{O}\right)$ & $\begin{array}{c}\text { Organic } \\
\mathrm{C}(\%)\end{array}$ & $\begin{array}{c}\text { Total N } \\
(\%)^{\mathrm{a}}\end{array}$ & $\begin{array}{c}\text { Clay } \\
(\%)\end{array}$ & $\begin{array}{c}\text { Silt } \\
(\%)\end{array}$ & $\begin{array}{c}\text { Sand } \\
(\%)\end{array}$ & $\begin{array}{c}\text { BD } \\
\left(\mathrm{kg} \mathrm{m}^{-3}\right)^{\mathrm{b}}\end{array}$ \\
\hline $0-30$ & 6.1 & 0.81 & 0.058 & 33 & 9 & 58 & 1500 \\
$30-60$ & 5.2 & 0.64 & 0.045 & 43 & 7 & 50 & 1550 \\
$60-180$ & 6.1 & 0.52 & 0.037 & 46 & 9 & 45 & 1500 \\
\hline
\end{tabular}

${ }^{a}$ Estimated using organic $\mathrm{C} \%$ measurement and a $\mathrm{C}: \mathrm{N}$ ratio of $14: 1$

${ }^{\mathrm{b}} \mathrm{BD}=$ Bulk density

\section{Management scenarios assessed}

A baseline scenario was set up to represent management practices common for the region, where irrigation scheduling is often based on farmer intuition and experience rather than any scientific rationale. Irrigation applications of $12.5 \mathrm{~mm}$ during crop establishment and $25 \mathrm{~mm}$ as crop water demand increased were used. A standard scheduling programme, utilising the full application of $1000 \mathrm{~mm}$ per season allocated to farmers in the region, was used and no flexibility in response to rainfall events was considered.

For the second scenario (named management scenario 1), an objective irrigation scheduling scenario using a soil water depletion threshold was assessed. The management aim 
of this scenario was to use less irrigation water than the allocated $1000 \mathrm{~mm}$ by scheduling more accurately according to crop demand while maintaining or even increasing current yields. Initially, irrigation applications rates of $12.5 \mathrm{~mm}$ were applied during crop establishment, thereafter $25 \mathrm{~mm}$ applications were automatically applied when soil water was depleted by 25 $\mathrm{mm}$.

For the third scenario (named management scenario 2), irrigation scheduling was determined as for management scenario 1 , but seasonal $\mathrm{N}$ fertilizer applications were reduced to take advantage of higher soil $\mathrm{N}$ levels due to reduced leaching losses (resulting from improved irrigation scheduling) and to make better use of $\mathrm{N}$ from newly mineralised organic matter simulated by the model to be approximately $100 \mathrm{~kg} \mathrm{~N} \mathrm{ha}^{-1}$ season $^{-1}$. This is in agreement with findings by Meyer et al. (1986), who estimated soil $\mathrm{N}$ mineralization rates between 79 and 135 $\mathrm{kg} \mathrm{N} \mathrm{ha}{ }^{-1}$ from the diagnostic top soil horizon of a Hutton soil form. The optimal fertilization rate of $100 \mathrm{~kg}$ urea- $\mathrm{N} \mathrm{ha}^{-1}$ was established by iteratively using the model to identify the rate at which yields are maintained while unwanted $\mathrm{N}$ losses to the environment are significantly reduced.

\section{Inventory analysis}

The 200 ha farm was assumed to be irrigated by $4 \times 50$ ha centre pivots. Each pivot was equipped with its own dedicated pump and motor. An estimated $19.9 \mathrm{~kW}$ was required by the pump to meet the flow and pressure needs, and an additional $4 \mathrm{~kW}$ to drive the wheels, for each 50 ha centre pivot.The total power requirements for the 200 ha irrigation system was therefore $95.6 \mathrm{~kW}$, or $0.48 \mathrm{~kW} \mathrm{ha}{ }^{-1}$. Farm mechanisation activities including ploughing, harrowing, ridging, verge control and agrochemical application was done using a $50 \mathrm{~kW}$ tractor. A 30 -ton infield road haulage rig and mechanical loader was assumed to transport the cane out of the field. Fertilizer and pesticides rates were based on South African Sugarcane Research Institute recommendations for the region as provided to farmers (Table II). Fertilizer was applied in a single application and broadcast shortly after planting or ratooning. Pre-harvest burning was assumed to burn $80 \%$ of trash and green leaves, with the non-burnt fraction being returned to the soil. 
Table II. Seasonal agrochemical, diesel and electricity inputs for the simulated commercial farm

\begin{tabular}{|c|c|c|c|}
\hline Inputs & Units & Rate & Comments \\
\hline \multicolumn{4}{|l|}{ Fertilizer } \\
\hline Nitrogen & $\mathrm{kg} \mathrm{ha}^{-1}$ & $150 / 100^{\mathrm{a}}$ & Applied as urea \\
\hline Phosphorus & $\mathrm{kg} \mathrm{ha}^{-1}$ & 20 & Applied as super phosphate \\
\hline Potassium & $\mathrm{kg} \mathrm{ha}^{-1}$ & 175 & Applied as potassium chloride \\
\hline Agricultural lime & $\mathrm{kg} \mathrm{ha}^{-1}$ & 0 & $\begin{array}{l}\text { Soil } \mathrm{pH} \text { did not warrant lime } \\
\text { application }\end{array}$ \\
\hline Irrigation water & $\mathrm{mm}$ & $1000 / 825^{b}$ & \\
\hline \multicolumn{4}{|l|}{ Pesticides (active ingredient) } \\
\hline Nematacide (plant) & $\mathrm{kg} \mathrm{ai}^{\mathrm{c}} \mathrm{ha}^{-1}$ & 3 & Prochloraz \\
\hline Nematacide (ratoon) & $\mathrm{kg}$ ai ha ${ }^{-1}$ & 7.2 & Oxamyl \\
\hline Herbicide (plant) & $\mathrm{kg}$ ai ha ${ }^{-1}$ & 3 & Diuron + Metribuzin \\
\hline Herbicide (ratoon) & $\mathrm{kg}$ ai ha ${ }^{-1}$ & 2.4 & Diuron + Hexazinone \\
\hline Insecticide & $\mathrm{kg}$ ai ha ${ }^{-1}$ & 0 & None used \\
\hline Fungicide & $\mathrm{kg}$ ai ha ${ }^{-1}$ & 0 & None used \\
\hline \multicolumn{4}{|l|}{ Energy/Fuel } \\
\hline Diesel (machinery) & $1 \mathrm{ha}^{-1}$ & 119 & Own figures (Based on SASRI, 2011) \\
\hline Electricity (irrigation) & $\mathrm{kWh} \mathrm{ha}^{-1}$ & $2118 / 1774^{b}$ & Own figures \\
\hline
\end{tabular}

${ }^{\mathrm{a}} 100 \mathrm{~kg} \mathrm{~N} \mathrm{ha}^{-1}$ applied to management scenario $2{ }^{\mathrm{b}}$ value for management scenarios 1 and 2 , ${ }^{\mathrm{c}}$ ai $=$ active ingredient

\section{Impact assessment}

The following environmental impact categories were assessed:

- $\quad$ non-renewable energy consumption considered total fossil fuel energy used to produce agrochemicals and to provide on-farm energy (electricity and diesel);

- global warming potential $(G W P)$ was calculated according to the Intergovernmental Panel on Climate Change (IPCC) (2006). GWP based on a 100 year time horizon is 310 for $\mathrm{N}_{2} \mathrm{O}$ and 21 for $\mathrm{CH}_{4}$. Indirect emissions of $\mathrm{N}_{2} \mathrm{O}$ from atmospheric deposition of $\mathrm{N}$ in $\mathrm{NO}_{\mathrm{x}}$ and $\mathrm{NH}_{3}$, and $\mathrm{N}$ leaching, were also considered according to IPCC (2006);

- $\quad$ acidification (air) and eutrophication (water) potentials were calculated according to the Eco-indicator 95 approach (Figure 2) (Goedkoop, 1995); 


\section{Emission Equivalence factor}

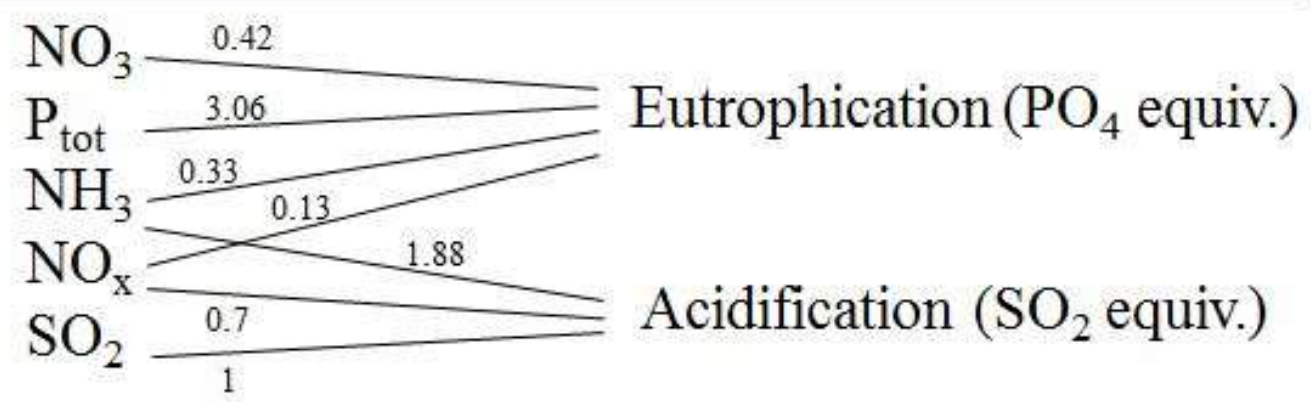

\section{Figure 2. Classification/characterisation of emissions using the Eco-indicator 95 method [adapted from Brentrup et al. (2001)]}

- water consumption based on Hoekstra et al. (2011). Blue water (surface water and groundwater that can be diverted to a range of human activities) and green water (water in the soil originating from rainfall) consumption was considered. Blue water consumption is equal to the amount irrigated (or modelled Irrigation Water Requirements IWR) and green water consumption equals cumulative evapotranspiration minus blue water consumption (or modelled total Crop Water Requirements CWR - IWR).

\section{RESULTS AND DISCUSSION}

\section{DSSAT-Canegro simulation results}

Improved irrigation scheduling led to slightly increased yields and an average reduced irrigation requirement of $175 \mathrm{~mm} \mathrm{ha}^{-1}$ per growing season (Table III). Average simulated extractable sucrose mass was $17.8 \mathrm{t} \mathrm{ha}^{-1}$ for the baseline scenario and $18.5 \mathrm{t} \mathrm{ha}^{-1}$ for the scenarios in which irrigation and irrigation and $\mathrm{N}$ were more carefully managed. These differences were found to be significantly different at the $5 \%$ level using a paired t-test. As there was no difference in yield between management scenarios 1 and 2, the estimated increase is attributed to improved irrigation water management. 
Table III. DSSAT-Canegro simulation outputs presented as growing season averages (with standard deviations) over the 16 year simulation period

\begin{tabular}{lccc}
\hline Simulation outputs & Unit & $\begin{array}{c}\text { Baseline } \\
\text { scenario }\end{array}$ & $\begin{array}{c}\text { Management } \\
\text { scenarios } 1 \& 2 *\end{array}$ \\
\hline Green cane mass & $\mathrm{t} \mathrm{ha}^{-1}$ & $116.9 \pm 5.2$ & $121.8 \pm 5.1$ \\
\hline Extractable sucrose yield & $\mathrm{t} \mathrm{ha}^{-1}$ & $17.8 \pm 0.96$ & $18.5 \pm 0.95$ \\
\hline Trash mass (dry mass) & $\mathrm{t} \mathrm{ha}^{-1}$ & $22.1 \pm 1.8$ & $23.1 \pm 1.0$ \\
\hline Evapotranspiration & $\mathrm{mm}$ & $1173 \pm 30$ & $1211 \pm 41$ \\
\hline Irrigation & $\mathrm{mm}$ & $1000 \pm 0$ & $825 \pm 122$ \\
\hline Rainfall & $\mathrm{mm}$ & $758 \pm 227$ & $758 \pm 227$ \\
\hline Deep drainage & $\mathrm{mm}$ & $432 \pm 125$ & $236 \pm 94$ \\
\hline Runoff & $\mathrm{mm}$ & $155 \pm 98$ & $122 \pm 94$
\end{tabular}

* Simulated crop yield and water balance outputs were the same for management scenarios 1 and 2

Compared to the baseline scenario, improved irrigation scheduling led to a simulated 196 $\mathrm{mm}(45 \%)$ reduction in average seasonal deep drainage and a $33 \mathrm{~mm}(21 \%)$ reduction in runoff. From Figure 3 it can, however, be observed that despite improved irrigation scheduling, high $\mathrm{N}$ leaching losses were still observed for management scenario 1 for certain seasons. In the final seasons of the simulation, cumulative $\mathrm{N}$ leaching was even higher for management scenario 1 than for the baseline scenario for two of the seasons. This is a result of the 'carry-over' effect, where inorganic $\mathrm{N}$ levels build-up in the soil as a result of previous seasons' fertilizer applications in excess of crop demand, eventually leading to relatively high $\mathrm{N}$ leaching concentrations and loads. Improved irrigation scheduling as well as reducing $\mathrm{N}$ fertilizer application rates to $100 \mathrm{~kg} \mathrm{ha}^{-1}$ led to drastic reductions in $\mathrm{N}$ leaching (Table III). The large seasonal variability observed for $\mathrm{N}$ leaching highlights the benefit of a mechanistic model to improve understanding on seasonal weather and past $\mathrm{N}$ fertilization management influences on $\mathrm{N}$ leaching, as opposed to using more simple emission factor approaches.

As the urea was simulated to be applied with the irrigation water (a common practice for farmers in the region), no $\mathrm{NH}_{3}$ volatilisation was predicted by the DSSAT model. Although negligible $\mathrm{NH}_{3}$ volatilisation has been observed as a result of improved management practices (eg. Rochette et al., 2013), the validity of this model output is open to scrutiny. 


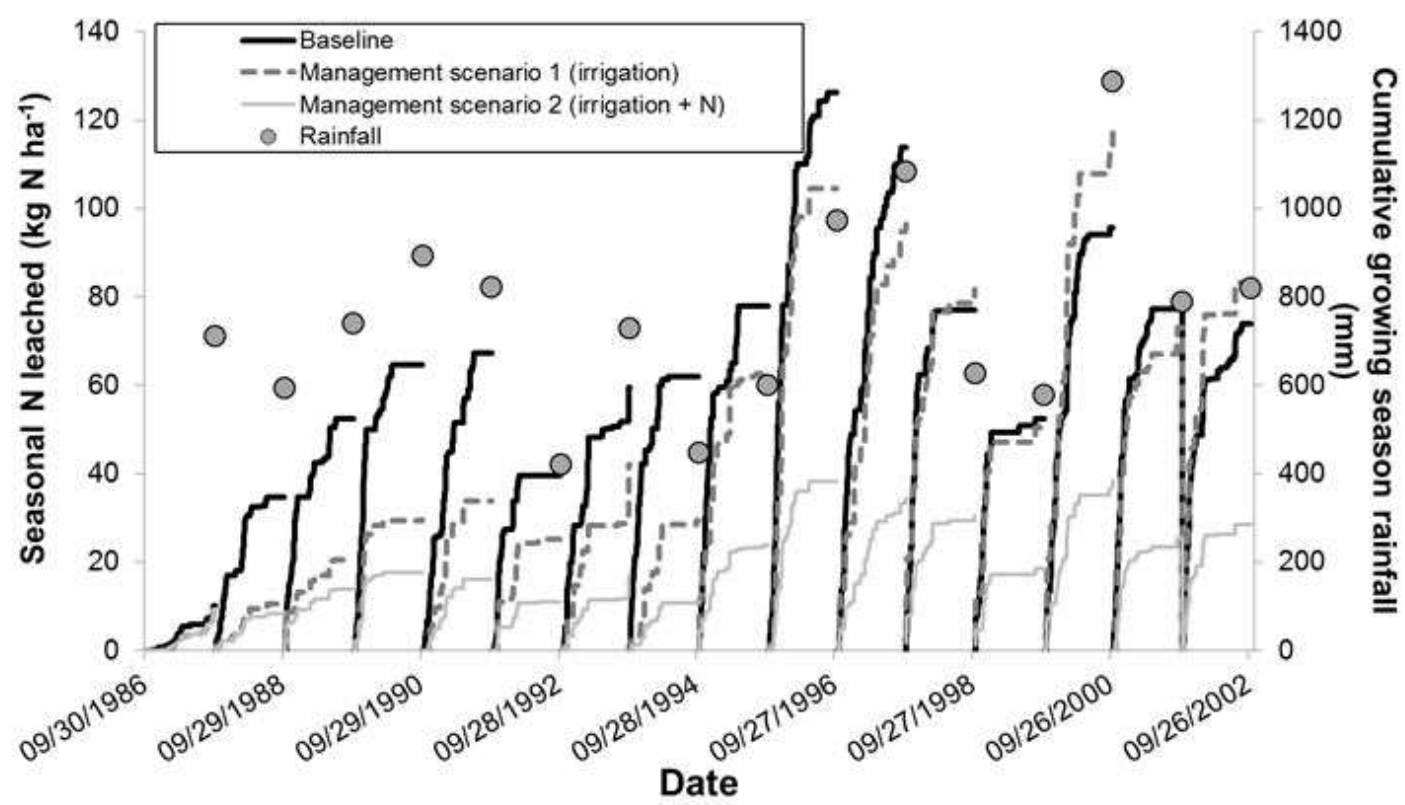

Figure 3. Simulated cumulative nitrogen $(\mathrm{N})$ leached and measured cumulative rainfall for each growing season for the three management scenarios. For management scenario 1, relatively high seasonal $\mathrm{N}$ leaching during the second half of the simulation was observed despite accurate irrigation scheduling as a result of a build-up of inorganic $\mathrm{N}$ in the soil profile due to applying fertilizer $\mathrm{N}$ in excess of crop demand ('carry-over effect')

Environmental impacts and energy use for different management scenarios

Table IV. Environmental impact indicators per functional unit (FU) according to management scenario

\begin{tabular}{|c|c|c|c|c|}
\hline Impact category & Unit/FU & $\begin{array}{l}\text { Baseline } \\
\text { scenario }\end{array}$ & $\begin{array}{c}\text { Management } \\
\text { scenario } 1\end{array}$ & Management scenario 2 \\
\hline Energy input & MJ & 1685 & 1553 & 1349 \\
\hline & $\mathrm{kg} \mathrm{CO}_{2^{-}}$ & & & \\
\hline Global Warming Potential (100) & e & 468 & 421 & 353 \\
\hline Acidification potential & $\mathrm{g} \mathrm{SO}_{2}-\mathrm{e}$ & 7.8 & 7.6 & 7.6 \\
\hline Eutrophication potential & $\mathrm{g} \mathrm{PO}_{4}-\mathrm{e}$ & 16.5 & 9.8 & 9.1 \\
\hline Blue water consumption & $\mathrm{m}^{3}$ & 562 & 446 & 446 \\
\hline Green water consumption & $\mathrm{m}^{3}$ & 97 & 209 & 209 \\
\hline
\end{tabular}

\section{Non-renewable energy consumption}

Non-renewable energy consumption ranged from 1349-1685 MJ tons sucrose ${ }^{-1}$ for the three scenarios simulated (Table IV). Scheduling irrigation objectively resulted in a $132 \mathrm{MJ}$ tons 
sucrose $^{-1}(8 \%)$ decrease in total energy input, and reducing $\mathrm{N}$ fertilizer rates as well further reduced energy input by an additional $204 \mathrm{MJ}$ tons sucrose ${ }^{-1}$ (20\% reduction from baseline scenario). Results are comparable with recently reported values from other sugarcane-producing regions around the world. Seabra et al. (2011) reported energy input requirements of $1109 \mathrm{MJ}$ tons sucrose ${ }^{-1}$ for the pre-dominantly rainfed Brazilian Centre-South Region. In comparison to our values of 205-257 MJ tons green cane ${ }^{-1}$, Renouf and Wegener (2007) reported energy inputs of 112-235 MJ tons green cane ${ }^{-1}$ for rainfed sugarcane production in Queensland, Australia. Interestingly, Ricau (1980) reported much higher energy inputs for sugarcane in Louisiana in the 1970s: about $8600 \mathrm{MJ}$ tons sucrose ${ }^{-1}$ and $645 \mathrm{MJ}$ tons green cane $\mathrm{s}^{-1}$, mostly owing to much lower yields and sucrose content. He also counted the energy embedded in farm machinery (manufacturing) which constitued about $13 \%$ of all energy inputs. Such difference, however, highlights the progress made in energy use-efficiency over recent decades in cane farming and equipment application (fuel-efficient engines, lighter equipment).

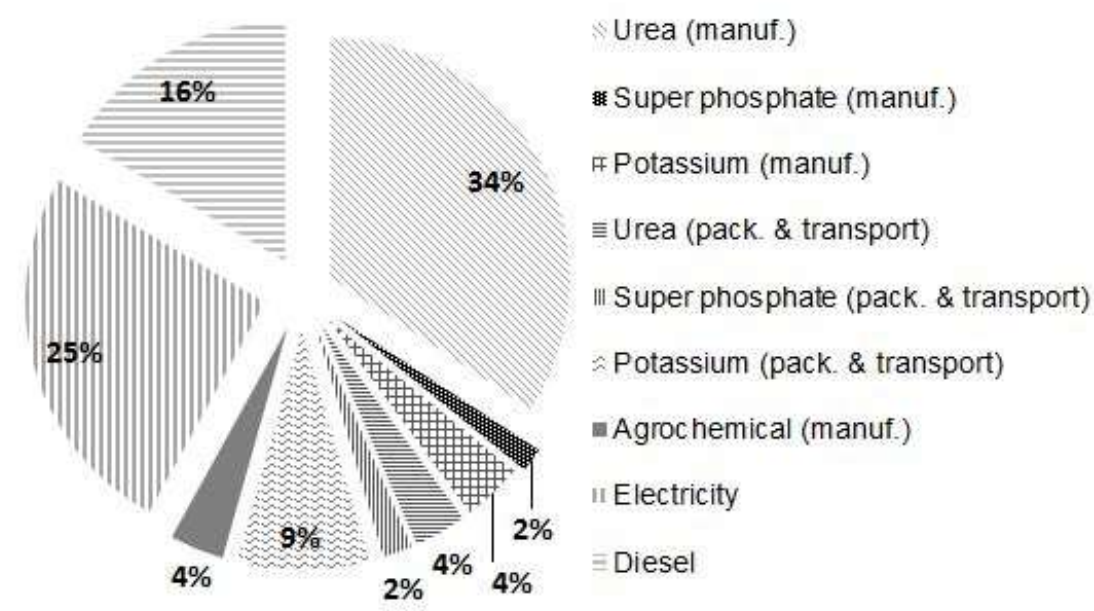

Figure 4. Relative contributions of important sugarcane production processes to non-renewable energy consumption for the baseline scenario

The manufacture of urea was responsible for the largest fraction of total energy input requirement (34\%), followed by electricity consumption for irrigation (25\%) and diesel use (16\%) (Figure 4). Using an ammonium-based fertilizer instead of urea at the $150 \mathrm{~kg} \mathrm{~N}^{-1}$ rate would lead to a $150 \mathrm{MJ}$ tons sucrose ${ }^{-1}(9 \%)$ reduction in energy input (based on an energy coefficient of $50.6 \mathrm{MJ} \mathrm{kg} \mathrm{N}{ }^{-1}$, Bhat et al. 1994), but farmers favour urea as it is significantly cheaper. Interestingly, packaging, storage and transport for the $\mathrm{K}$ fertilizer contributed the next highest fraction to energy input requirements for the baseline scenario at $9 \%$, representing more 
Table V. Pollutant emissions and non-renewable energy consumption for the simulated commercial farm

\begin{tabular}{|c|c|c|c|c|c|}
\hline & Units/ha & $\begin{array}{l}\text { Baseline } \\
\text { scenario }\end{array}$ & $\begin{array}{l}\text { Management } \\
\text { scenario } 1\end{array}$ & $\begin{array}{c}\text { Management } \\
\text { scenario } 2\end{array}$ & \\
\hline EMISSION DESCRIPTION & & & & & Emission Factor/Reference \\
\hline \multicolumn{6}{|l|}{ Field emissions to air } \\
\hline $\mathrm{N}_{2} \mathrm{O}$ (denitrification) & $\mathrm{kg}$ & 1.63 & 0.90 & 0.49 & $\begin{array}{l}\text { DSSAT-Canegro (Van der Laan et al. 2011); } \mathrm{N}_{2} / \mathrm{N}_{2} \mathrm{O} \\
\text { estimated using Del Grosso et al. (2000) }\end{array}$ \\
\hline$N_{2}$ (denitrification) & $\mathrm{kg}$ & 4.26 & 2.33 & 1.27 & $\begin{array}{l}\text { DSSAT-Canegro (Van der Laan et al. 2011); } \mathrm{N}_{2} / \mathrm{N}_{2} \mathrm{O} \\
\text { estimated using Del Grosso et al. (2000) }\end{array}$ \\
\hline $\mathrm{NH}_{3}$ (volatilisation) & $\mathrm{kg}$ & 0 & 0 & 0 & DSSAT-Canegro (Van der Laan et al. 2011) \\
\hline$N O_{x}($ nitrification + denitrification $)$ & $\mathrm{kg}$ & 0.75 & 0.75 & 0.5 & $0.005 \mathrm{~kg} / \mathrm{kg} \mathrm{N}$ applied (Ramjeawon, 2004) \\
\hline Land use $\mathrm{CO}_{2}$ emissions & $\mathrm{kg}$ & 0 & 0 & 0 & 'Cropland remaining cropland' (IPCC, 2006) \\
\hline $\mathrm{N}_{2} \mathrm{O}$ (indirect as a result of $\mathrm{N}$ leaching) & $\mathrm{kg}$ & 0.80 & 0.64 & 0.31 & $0.0075 \mathrm{~kg} \mathrm{~N} 2 \mathrm{O}-\mathrm{N} / \mathrm{kg}$ N leached (IPCC, 2006) \\
\hline \multicolumn{6}{|l|}{ Field emissions to water } \\
\hline $\mathrm{NO}_{3}$-N leaching & $\mathrm{kg}$ & 67.9 & 54.7 & 26.4 & DSSAT-Canegro (Van der Laan et al. 2011) \\
\hline P leaching & $\mathrm{g}$ & 77.8 & 42.5 & 42.5 & $0.18 \mathrm{~g} \mathrm{P} / \mathrm{mm}$ drainage (Thompson, 1991) \\
\hline P runoff & $\mathrm{kg}$ & 2.6 & 2.6 & 2.6 & $0.128 \mathrm{~kg} / \mathrm{kg}$ P applied (Renouf et al. 2008) \\
\hline Pesticide leaching/runoff & $\mathrm{kg}$ & 0.14 & 0.14 & 0.14 & $0.015 \mathrm{~kg} / \mathrm{kg}$ ai $^{\mathrm{a}}($ Renouf et al. 2008) \\
\hline \multicolumn{6}{|l|}{ Pre-harvest burning emissions to air } \\
\hline $\mathrm{CH}_{4}$ & $\mathrm{~kg}$ & 47.7 & 50.1 & 50.1 & $0.0027 \mathrm{~kg} / \mathrm{kg} \mathrm{DM}^{\mathrm{b}}$ (Bernoux et al. 2011) \\
\hline $\mathrm{N}_{2} \mathrm{O}$ & $\mathrm{kg}$ & 1.2 & 1.3 & 1.3 & $0.00007 \mathrm{~kg} / \mathrm{kg}$ DM (Bernoux et al. 2011) \\
\hline $\mathrm{NH}_{3}$ & $\mathrm{~kg}$ & 42.4 & 44.5 & 44.5 & $0.0024 \mathrm{~kg} / \mathrm{kg}$ DM (EEA, 2009) \\
\hline$N O_{x}$ & $\mathrm{~kg}$ & 42.4 & 44.5 & 44.5 & 0.0024 kg/kg DM (EEA, 2009) \\
\hline$S O_{x}$ & $\mathrm{~kg}$ & 5.3 & 5.6 & 5.6 & $0.0003 \mathrm{~kg} / \mathrm{kg}$ DM (EEA, 2009) \\
\hline
\end{tabular}




\begin{tabular}{|c|c|c|c|c|c|}
\hline \multicolumn{6}{|l|}{ Input emissions to air } \\
\hline Urea & $\mathrm{kg} \mathrm{CO}_{2}$-e & 3086 & 3086 & 2057 & $4.8 \mathrm{~kg} \mathrm{CO}_{2} / \mathrm{kg}$ product (Lal, 2004) \\
\hline Super phosphate & $\mathrm{kg} \mathrm{CO}$-e & 50 & 50 & 50 & $0.7 \mathrm{~kg} \mathrm{CO}_{2} / \mathrm{kg}$ product (Lal, 2004) \\
\hline Potassium & $\mathrm{kg} \mathrm{CO}$-e & 200 & 200 & 200 & $0.6 \mathrm{~kg} \mathrm{CO}_{2} / \mathrm{kg}$ product (Lal, 2004) \\
\hline Lime & $\mathrm{kg} \mathrm{CO}_{2}$-e & 0 & 0 & 0 & $\begin{array}{l}0.12 \text { for limestone } / 0.13 \text { for dolomite }-\mathrm{kg} \mathrm{CO}_{2} / \mathrm{kg} \text { product } \\
\text { (IPCC, 2006) }\end{array}$ \\
\hline Nematacide & $\mathrm{kg} \mathrm{CO}$-e & 125 & 125 & 125 & $18.7 \mathrm{~kg} \mathrm{CO}_{2} / \mathrm{kg}$ ai $(\mathrm{Lal}, 2004)$ \\
\hline Herbicide & $\mathrm{kg} \mathrm{CO}$-e & 57 & 57 & 57 & $23.1 \mathrm{~kg} \mathrm{CO}_{2} / \mathrm{kg}$ ai $(\mathrm{Lal}, 2004)$ \\
\hline Insecticide & $\mathrm{kg} \mathrm{CO}$-e & 0 & 0 & 0 & $18.7 \mathrm{~kg} \mathrm{CO}_{2} / \mathrm{kg}$ ai $(\mathrm{Lal}, 2004)$ \\
\hline Fungicide & $\mathrm{kg} \mathrm{CO}_{2}$-e & 0 & 0 & 0 & $14.3 \mathrm{~kg} \mathrm{CO}_{2} / \mathrm{kg}$ ai $(\mathrm{Lal}, 2004)$ \\
\hline Diesel & $\mathrm{kg} \mathrm{CO}$-e & 313 & 313 & 313 & $2.63 \mathrm{~kg} \mathrm{CO}_{2} / \mathrm{l}$ (Bernoux et al., 2011) \\
\hline Electricity $\left(\mathrm{CO}_{2}\right)$ & $\mathrm{kg} \mathrm{CO} \mathrm{CO}_{2}$ & 2076 & 1730 & 1730 & $0.98 \mathrm{~kg} \mathrm{CO}_{2} / \mathrm{kWh}(\mathrm{ESKOM}, 2010)$ \\
\hline Electricity $\left(S O_{x}\right)$ & $\mathrm{kg} \mathrm{SO}_{\mathrm{x}}$ & 17 & 14 & 14 & $8.1 \mathrm{~g} \mathrm{SO}_{\mathrm{x}} / \mathrm{kWh}(\mathrm{ESKOM}, 2010)$ \\
\hline Electricity $\left(N O_{x}\right)$ & $\mathrm{kg} \mathrm{NO}$ & 9 & 7 & 7 & $4.17 \mathrm{~g} \mathrm{NO}_{\mathrm{x}} / \mathrm{kWh}(\mathrm{ESKOM}, 2010)$ \\
\hline NON-RENEWABLE ENERGY INPUT & & & & & Energy coefficient/Reference \\
\hline Urea (manufacture) & MJ & 10262 & 10262 & 6841 & $68.41 \mathrm{MJ} / \mathrm{kg}$ urea-N (Bhat et al. 1994) \\
\hline Super phosphate (manufacture) & MJ & 489 & 489 & 489 & $6.82 \mathrm{MJ} / \mathrm{kg} \mathrm{P}_{2} \mathrm{O}_{5}$ (Bhat et al. 1994) \\
\hline Potassium (manufacture) & MJ & 1214 & 1214 & 1214 & $2.88 \mathrm{MJ} / \mathrm{kg} \mathrm{K} \mathrm{O}_{2} \mathrm{O}$ (Bhat et al. 1994) \\
\hline Urea (pack. and transport) & MJ & 1058 & 1058 & 705 & 7.05 MJ/kg N (Mudahar and Hignett, 1987) \\
\hline Super phosphate (pack. and transport) & MJ & 597 & 597 & 597 & $8.33 \mathrm{MJ} / \mathrm{kg} \mathrm{P}_{2} \mathrm{O} 5$ (Mudahar and Hignett, 1987) \\
\hline Potassium (pack. and transport) & MJ & 2677 & 2677 & 2677 & $6.35 \mathrm{MJ} / \mathrm{kg} \mathrm{K} \mathrm{K}_{2} \mathrm{O}$ (Mudahar and Hignett, 1987) \\
\hline Pesticide (manufacture) & MJ & 1098 & 1098 & 1098 & $120 \mathrm{MJ} / \mathrm{kg}$ of ai (Mashoko et al. 2010) \\
\hline Pesticide (pack. and transport) & MJ & 27 & 27 & 27 & $3 \mathrm{MJ} / \mathrm{kg}$ of ai (Helsel, 1992) \\
\hline Electricity & MJ & 7625 & 6354 & 6354 & 3.6 MJ/kWh (Statistics South Africa, 2005) \\
\hline Diesel & MJ & 4950 & 4950 & 4950 & 41.6 MJ/kWh (Statistics South Africa, 2005) \\
\hline
\end{tabular}

${ }^{\mathrm{a}}$ ai $=$ active ingredient, ${ }^{\mathrm{b}} \mathrm{DM}=$ dry matter 
than double the energy input for the manufacture of K fertilizer.

\section{Global warming potential}

Pollutant emissions and the methodology used to estimate them are presented in Table V. Total greenhouse gas emissions were reduced from 468 to $421 \mathrm{~kg} \mathrm{CO}_{2}$-e (carbon dioxide equivalents) tons sucrose ${ }^{-1}$ by improving irrigation scheduling and to $353 \mathrm{~kg} \mathrm{CO}_{2}$-e tons sucrose $\mathrm{e}^{-}$

${ }^{1}$ (25\% decrease) by further reducing urea fertilizer application rates by $50 \mathrm{~kg} \mathrm{~N}$ ha ${ }^{-1}$. These results compare very closely to estimates of $490 \mathrm{~kg} \mathrm{CO}_{2}$-e tons sugar ${ }^{-1}$ for a study conducted in Thailand (Yuttitham et al., 2011). Emissions related to fertilizer production, storage and transport was responsible for $41 \%$ of total $\mathrm{CO}_{2}$-e emissions per ton of sucrose for the baseline scenario, with urea production, storage and transport alone being responsible for $37 \%$ of total $\mathrm{CO}_{2}$-e emissions per ton of sucrose (Figure 5). Also for the baseline scenario, electricity generation for irrigation purposes was estimated to contribute $25 \%$ of total $\mathrm{CO}_{2}$-e emissions per ton of sucrose, followed closely by emissions from crop burning, which contributed $19 \%$ of total $\mathrm{CO}_{2}$-e emissions per ton of sucrose.

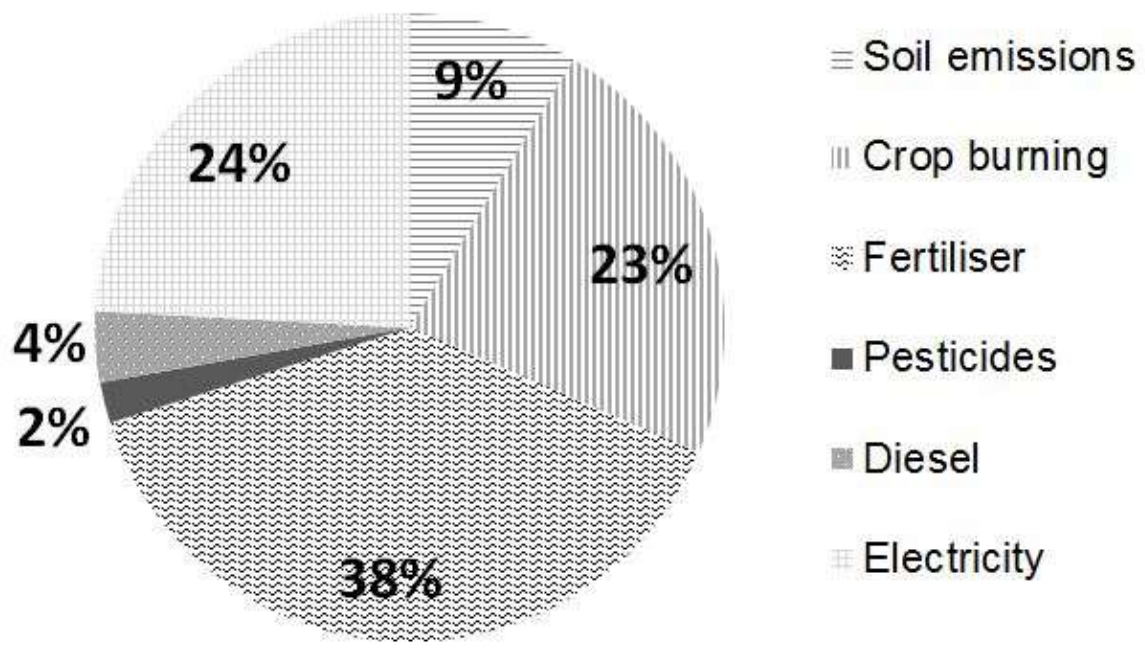

Figure 5. Relative contributions of important sugarcane production processes to total global warming potential for the baseline scenario

Based on coefficients of variation, emission estimate uncertainty ranges of $40 \%$ for fuel use, $7 \%$ for manufacture of synthetic $\mathrm{N}$ fertilizers and $70 \%$ for soil $\mathrm{N}_{2} \mathrm{O}$ emissions have been reported (Williams et al., 2006; Tuomisto et al., 2012). Using the DSSAT-Canegro model and 
Del Grosso et al. (2002) approach, average seasonal $\mathrm{N}_{2} \mathrm{O}$ emissions were estimated to range from $1.63 \mathrm{~kg} \mathrm{ha}^{-1}$ for the baseline scenario to $0.49 \mathrm{~kg} \mathrm{ha}^{-1}$ for the scenario in which water and $\mathrm{N}$ were more carefully applied according to crop demand. These estimates are lower than those measured under sugarcane by Denmead et al. (2010), who observed $\mathrm{N}_{2} \mathrm{O}$ emissions of $7.4 \mathrm{~kg}$ ha ${ }^{-}$

${ }^{1}$ on a sandy loam soil with $1.7 \%$ organic $\mathrm{C}$ fertilized with $150 \mathrm{~kg}$ urea ha ${ }^{-1}$. Following a simulation study, Thorburn et al. (2010) estimated that $\mathrm{N}_{2} \mathrm{O}$ emissions from sugarcane production for a range of environments in Australia are commonly equivalent to 3-5\% of applied fertilizer $\mathrm{N}$. Using the IPCC emission factor of $0.01 \mathrm{~kg} \mathrm{~N}_{2} 0-\mathrm{N} \mathrm{kg}$ fertilizer $\mathrm{N}^{-1}$ (IPCC, 2006) results in a $\mathrm{N}_{2} \mathrm{O}$ emission estimate of $2.4 \mathrm{~kg} \mathrm{~N}_{2} \mathrm{O}$ ha $^{-1}$ for scenarios receiving $150 \mathrm{~kg}$ fertilizer $\mathrm{N} \mathrm{ha}^{-1}$ and $1.6 \mathrm{~kg} \mathrm{~N}_{2} \mathrm{O}$ ha $^{-1}$ for the scenario receiving $100 \mathrm{~kg}$ fertilizer $\mathrm{N} \mathrm{ha}^{-1}$. We speculate that the low emission estimates in this study are a result of the system not being trashblanketed, which potentially leads to heightened denitrification rates as a result of increased soil labile $\mathrm{C}$ availability to microbes and prolonged soil water saturation conditions due to reduced evaporation.

\section{Eutrophication potential}

The eutrophication potential was estimated at $16.5 \mathrm{~g} \mathrm{PO}_{4}$-e (phosphate equivalents) tons sucrose $^{-1}$ for the baseline scenario, $9.8 \mathrm{~g} \mathrm{PO}_{4}$-e tons sucrose ${ }^{-1}$ for management scenario 1 , and $9.1 \mathrm{~g} \mathrm{PO}_{4}$-e tons sucrose $\mathrm{e}^{-1}$ for management scenario 2. Based on seasonal averages, DSSATCanegro estimated that $45 \%, 37 \%$ and $26 \%$ of applied fertilizer $\mathrm{N}$ leached for the baseline, management 1 and management 2 scenarios, respectively. Using the IPCC (2006) default emission factor for $\mathrm{N}$ leaching of $30 \%$ of applied fertilizer $\mathrm{N}$, leaching would have been underestimated for the baseline scenario and to a lesser extent for management scenario 1, and slightly over-estimated for management scenario 2 . Nitrogen loss via runoff was not considered as DSSAT-Canegro does not simulate this and there is a lack of information to estimate these losses. The $\mathrm{P}$ leaching factor of $0.18 \mathrm{~g} \mathrm{P} \mathrm{mm} \mathrm{drainage}{ }^{-1}$ was derived from lysimeter data (Thompson, 1991) and is specific to this soil and cropping system. According to Hoekstra et al. (2011), impact on water quality also needs to be considered from a geographic perspective, including the effects on seasonal water flow and quality in the specific catchment. The deterioration of water quality observed for the Pongola River is a concern (Van der Laan et al., 2012), and improving irrigation scheduling and $\mathrm{N}$ management can potentially reduce irrigation's contribution to pollutant loads.

\section{Acidification potential}

Acidification potential, resulting from the release of $\mathrm{SO}_{\mathrm{x}}, \mathrm{NO}_{\mathrm{x}}$ and $\mathrm{NH}_{3}$ gases during 
electricity generation, diesel combustion and pre-harvest burning was estimated to be $7.8 \mathrm{~g} \mathrm{SO}_{2^{-}}$ e tons sucrose $\mathrm{e}^{-1}$ for the baseline scenario and $7.6 \mathrm{~g} \mathrm{SO}_{2}$-e tons sucrose ${ }^{-1}$ for the improved scheduling scenarios. For the baseline scenario, $\mathrm{NH}_{3}$ and $\mathrm{NO}_{\mathrm{x}}$ emissions from green leaf and trash burning contributed to $80 \%$ of this impact, and $\mathrm{SO}_{\mathrm{x}}$ emissions from electricity generation for irrigation contributed 12\%. Pre-harvesting burning is expected to be phased out in South Africa and the acidification potential will be subsequently reduced.

\section{Water consumption}

While total water consumption was very similar between the baseline and objectively irrigated scenarios $\left(659 \mathrm{~m}^{3}\right.$ and $655 \mathrm{~m}^{3}$ tons sucrose ${ }^{-1}$, respectively), blue and green water consumption differed notably between scenarios. Green water consumption for the improved scheduling scenarios (209 $\mathrm{m}^{3}$ tons sucrose $\mathrm{e}^{-1}$ or $32 \%$ of total consumption) was more than double that of the baseline scenario ( $97 \mathrm{~m}^{3}$ tons sucrose $\mathrm{e}^{-1}$ or $15 \%$ of total consumption). Increased use of green water (rainfall and soil water) is favourable as it reduces energy requirements and greenhouse gas emissions associated with irrigation, extracts less water from surface and subsurface resources, allowing for larger environmental flow, and potentially reduces pollution loads returning to the river via agricultural return flows. The water saved may then be used to irrigate larger areas of land or be diverted to other users. Of the total blue water consumption, water used during electricity generation amounted to only $0.02 \%$ of the total.

\section{IMPROVEMENT NEEDS AND OPPORTUNITIES FOR LIFE CYCLE ASSESSMENT OF IRRIGATED CROPPING SYSTEMS}

Through partial application of LCA methodology coupled with crop modelling, the environmental impact of sugarcane produced under irrigation for site-specific conditions and varied management practices has been quantified. Water and $\mathrm{N}$ management were shown to significantly influence a range of environmental impacts. In addition to escalating irrigation water, fertilizer and electricity costs motivating farmers to optimize irrigation and $\mathrm{N}$ fertilizer scheduling (Annandale et al., 2011), these results on environmental impacts can serve as further motivation for farmers. Advances in technology to better quantify soil water content levels, crop $\mathrm{N}$ status and soil $\mathrm{N}$ mineralization potential provide farmers with the means to do so.

While the use of mechanistic modelling enhanced the ability to evaluate improved management practices, adequate data for model calibration purposes to gain confidence in outputs is not often available. In these cases crop models should be used with caution, and 
sensitivity analyses will be important to better understand the influence of parameterisation and initialisation values on results. Furthermore, even well-calibrated mechanistic models have their limitations. For example, the impact of varying water and $\mathrm{N}$ regimes during sugarcane growth on the sucrose content of harvested cane is not yet mechanistically simulated in the DSSATCanegro model.

In this study, data was used for a soil with relatively high water holding capacity and $\mathrm{N}$ mineralisation potential. In contrast, a sandier and/or shallower soil will enable less efficient use of rainfall and require more frequent irrigation applications and higher volumes to achieve similar yields. Nitrogen dynamics would also be modified, for example, there would be a smaller contribution of mineralised $\mathrm{N}$ from organic matter and leaching risks would be higher. Associated impacts can therefore be expected to be different for a sandier/shallower soil, and further work is required to fully understand the transferability of results to sugarcane agroecosystems with different characteristics.

In addition to irrigation water and $\mathrm{N}$ management, results show that discontinuing preharvest sugarcane burning practices can significantly reduce the acidification potential impact and to a lesser extent GWP. The impacts of green cane harvesting will need to be assessed to determine whether any pollution swapping is taking place. For example, soil $\mathrm{N}_{2} \mathrm{O}$ emissions may increase significantly as a result of the presence of a trash blanket. The importance of electricity use in GWP comes from the 'electricity mix' in South Africa, which is mostly coalfuel burning based. If cane trash could be used at the mill for the co-generation of electricity, this could be reduced significantly.

Only limited work has been done on the fate and export of pesticides from irrigated sugarcane fields at a global scale (Davis et al., 2011). Due to lack of information for South Africa on the fate of pesticides in the plant, soil, air and water compartments, or their concentration in the different parts of the plant (e.g. what is burnt, what stays in the rooting system, what is exported), it was decided to ignore human- and eco-toxicity impacts. Further work is therefore required in countries such as South Africa, Australia and India for the inclusion of these impact categories in the LCA framework.

Salt loads from irrigated lands to rivers can be substantial (Branson et al., 1975). Interestingly, salinity impacts (e.g. from irrigation return flow containing high salt loads) are not routinely considered in LCAs. This impact arises from a specific type of pollution wherein evaporation results in an increase in concentration, as opposed to the addition of a new chemical to the water (Hoekstra et al., 2011). Distinguishing between salt export resulting from irrigation activities and natural weathering is challenging. Leske and Buckley (2004) argue that salinity impacts, including impacts other than toxic effects alone, have clear cause-effect relationships 
between the sources and the impacts, warranting a separate salinity impact category. In water footprint assessments, Hoekstra et al. (2011) proposed the 'grey water' concept, which refers to 'the volume of freshwater that is required to assimilate the load of pollutants based on natural background concentrations and existing ambient water quality standards'. Clearly, innovative methods to quantify the impact of salinity from cropping systems within LCA frameworks are required.

A number of approaches for estimating water footprints have been proposed (Pfister et al., 2009; Milà i Canals et al., 2009; Deurer et al., 2011; Hoekstra et al., 2011), each with its own strengths and weaknesses. Depending on the context of the study, region-specific approaches that take location into account and quantify the impact of water consumption on resource depletion at catchment to basin scales may be needed. For example, Pfister et al. (2009) suggested relating any water consumption calculated during LCA inventory stage to a regional Water Stress Index (WSI), so that an impact indicator - showing how impactful sitespecific water consumption really is - may be derived. The official release of the ISO 14046 standards on water footprinting, which are scheduled for publication in 2014, may serve to standardize the approaches followed in future studies.

Abiotic resource depletion is often considered in LCA's. Brentrup et al. (2002) question the aggregation of various resources into a single impact category, proposing instead the use of separate impact sub-categories (fossil fuels, phosphate rock and potash salt for agricultural production systems) with resources only aggregated according to primary function. Our concern with this impact category is that a production system might be 'penalised' for applying fertilizer or manure $\mathrm{P}$ in a particular season, while not accounting for historical $\mathrm{P}$ applications that have built up in the soil or the mining of soil P reserves. LCA done in any given year may, therefore, show small impacts, while actual impacts were huge in the past due to over application. A possible way to overcome this will be to rather consider $\mathrm{P}$ and $\mathrm{K}$ 'consumption', i.e. total $\mathrm{P}$ and $\mathrm{K}$ lost from the system via harvested fractions.

Land use, as an impact category, refers to the environmental impacts of occupying and utilizing land for sugar cane, with potential resultant loss of natural habitat and species diversity (Brentrup et al., 2004a). Koellner et al. (2013) propose a multi-level classification of land use with four levels of detail, from general to very specific categories indicating intensity of land use. For regionalization, five levels are proposed allowing specification of climatic region, specific biomes and ecoregions. This classification system can assist refinement of methods to determine the impacts of land use on, for example, biodiversity and ecosystem services, and is recommend for studies comparing sugar production in different regions around the world. For example, rainfed sugarcane production will consume no blue water, but may come at a greater 
cost to biodiversity.

The exclusion of a number of processes in LCA means the relative difference in environmental impact between the compared systems may be over-emphasized. In other words, the differences between systems may actually be smaller if one considers another functional unit, for example, a kg of sugar delivered at retail level. In this study, however, all excluded processes are common to the scenarios under scrutiny, so inclusion of such processes would not have significantly changed the outcome / ranking provided by the comparative analysis.

\section{CONCLUSION}

Pressure on agricultural supply chains for better environmental stewardship is increasing. Combining LCA approaches and mechanistic crop modelling can be effective in evaluating the impact of improved management practices on a range of production-related environmental impacts. Consideration of multiple impacts simultaneously also monitors for any problem shifting or 'pollution swapping'. Such a framework therefore serves to clarify the linkages and associated knock-on impacts of irrigation water and $\mathrm{N}$ fertilizer management, and helps to identify leverage points which have far reaching consequences/benefits.

The overall environmental impact of sugarcane production can be reduced significantly not only at crop production stages but also through the co-generation of electricity using sugarcane fibre and bio-ethanol generation. Future work expanding the framework developed here to include milling processes and the benefits and impacts of mill by-products is essential. The methodology is continually open to further scientific progress and new information (Udo de Haes et al., 1999). Linking with economic aspects should also be considered.

Crop modelling combined with LCA shows excellent potential in improving communication between scientists, farmers and other stake holders, and to assist in identifying mitigation management practices and policies to reduce the environmental footprint of food production.

\section{REFERENCES}

Annandale JG, Stirzaker RJ, Singels A, van der Laan M, Laker MC. 2011. Irrigation scheduling research: South African experiences and future prospects. Water SA 37: 751-764.

Bernoux M, Tinlot M, Bockel L, Branca G, Gentien A. 2011. Ex-Ante Carbon Balance Tool 
(EX-ACT): Technical Guidelines for Version 3.0. FAO, Rome, pp. 44.

Bhat MG, English BC, Turhollow AF, Nyangito HO. 1994. Energy in Synthetic Fertilizers and Pesticides: Revisited. ORNL/Sub/90-99732/2. Oak Ridge National Laboratory, Oak Ridge, TN, Department of Energy, USA, pp. 49.

Blengini GA, Busto M. 2009. The life cycle of rice: LCA of alternative agri-food chain management systems in Vercelli (Italy). Journal of Environmental Management 90: 1512-1522.

Branson RL, Pratt PF, Rhoades JD, Oster JD. 1975. Water quality in irrigated watersheds. Journal of Environmental Quality 40: 33-40.

Brentrup F, Küsters J, Kuhlmann H, Lammel J. 2001. Application of the Life Cycle Assessment methodology to agricultural production: an example of sugar beet production with different forms of nitrogen fertilizers. European Journal of Agronomy 14: 221-233.

Brentrup F, Küsters J, Kuhlmann H, Lammel J. 2004a. Environmental impact assessment of agricultural production systems using the life cycle assessment (LCA) methodology I. Theoretical conception of a LCA method tailored to crop production. European Journal of Agronomy 20: 247-264.

Brentrup F, Küsters J, Lammel J, Barraclough P, Kuhlmann H. 2004b. Environmental impact assessment of agricultural production systems using the life cycle assessment (LCA) methodology II. The application to $\mathrm{N}$ fertilizer use in winter wheat production systems. European Journal of Agronomy 20: 265-279.

Brentrup F, Küsters J, Lammel J, Kuhlmann H. 2002. Impact assessment of abiotic resource depletion. International Journal of Life Cycle Assessment 7: 301-307.

Cluverwell TL, Proksch L, Swart C. 1999. A practical irrigation scheduling method for sugarcane crops. Proceedings of the South African Sugar Technologists Association 73: 69-73.

Contreras AM, Rosa E, Pérez M, van Langenhove H, Dewulf J. 2009. Comparative Life Cycle Assessment of four alternatives for using by-products of cane sugar production. Journal of Cleaner Production 17: 772-779.

Davis AM, Thorburn PJ, Lewis SE, Bainbridge ZT, Attard SJ, Milla R, Brodie JE. Environmental impacts of irrigated sugarcane production: Herbicide run-off dynamics from farms and associated drainage systems. Agriculture, Ecosystems and Environment (2011) in press doi:10.1016/j.agee.2011.06.019

Del Grosso SJ, Parton WJ, Mosier AR, Ojima DS, Kulmala AE, Phongpan S. 2000. General model for $\mathrm{N}_{2} \mathrm{O}$ and $\mathrm{N}_{2}$ gas emission from soils due to nitrification. Global Biogeochemical Cycles 14: 1045-1060. 
Deurer M, Green SR, Clothier BE, Mowat A (2011) Can product water footprints indicate the hydrological impact of primary production? - A case study of New Zealand kiwifruit. Journal of Hydrology 408: 246-256.

Department of Water Affairs and Forestry (DWAF). 2004. National Water Resource Strategy. (1st edn.). September 2004. Department of Water Affairs and Forestry, Pretoria, South Africa, pp 150.

European Environment Agency (EEA). 2009. EMEP/EEA air pollutant emission inventory guidebook. Technical report No 9/2009, Copenhagen, Denmark. Available from <http://www.eea.europa.eu/publications/emep-eea-emission-inventory-guidebook-2009>

$\begin{array}{llllll}\text { ESKOM. 2010. ESKOM Integrated Report. Available from } & \text { R }\end{array}$ <http://financialresults.co.za/2010/eskom_ar2010/downloads/eskom_ar2010.pdf>

Finnveden G, Hauschild MZ, Ekvall T, Guinée J, Heijungs R, Hellweg S, Koehler A, Pennington D, Suh S. 2009. Recent developments in life cycle assessment. Journal of Environmental Management 91: 1-21.

Goedkoop M. 1995. The Eco-Indicator 95. NOH report 9523. Final Report. Pré Consultants, Amersfoort, Netherlands. pp 85.

Helsel ZR. 1992. Energy and Alternatives for Fertilizer and Pesticide use, in: Fluck R.C. (Ed.) Energy in World Agriculture 6. Elsevier, Amsterdam, Netherlands, pp 177-201.

Hoekstra AY, Chapagain AK, Aldaya MM, Mekonnen MM. 2011. The water footprint assessment manual: setting the global standard. Earthscan, London, United Kingdom, pp 203.

Hurst CA, Thorburn PJ, Lockington D, Bristow KL. 2004. Sugarcane water use from shallow water tables: implications for improving irrigation water use efficiency. Agricultural Water Management 65: 1-19.

Jones JW, Hoogenboom G, Porter CH, Boote KJ, Batchelor WD, Hunt LA, Wilkens PW, Singh U, Gijsman AJ, Ritchie JT. 2003. The DSSAT cropping system model. European Journal of Agronomy 18: 235-265

Ingram KT, Hilton HW. 1986. Nitrogen-potassium fertilization and soil moisture effects on growth and development of drip-irrigated sugarcane. Crop Science 26: 1034-1039.

Inman-Bamber NG, Zund PR, Muchow RC. 2000. Water use efficiency and soil water availability for sugarcane. Proceedings of the Australian Society Sugar Cane Technologists 22: 264-269.

Intergovernmental Panel on Climate Change (IPCC). 2006. Guidelines for National Greenhouse Gas Inventories, Eggleston H.S., Buendia, L., Miwa, K., Ngara, T., Tanabe, K. (Eds.) National Greenhouse Gas Inventories Programme, Hayama, Japan. 
Kingston G. 1994. Benchmarking yield of sugarcane from estimates of crop water use. Proceedings of the Australian Society Sugar Cane Technologists 16: 201-209.

Koellner T, de Baan L, Beck T, Brandão M, Civit B, Goedkoop M, Margni M, Milà i Canals L, Müller-Wenk R, Weidma, B, Wittstock, B. (2013). Principles for life cycle inventories of land use on a global scale. The International Journal of Life Cycle Assessment 18: 12031215.

Lal R. 2004. Carbon emissions from farm operations. Environment International 30: 981-990.

Leske T, Buckley C. 2003. Towards the development of a salinity impact category for South African environmental life-cycle assessments: Part 1 - A new impact category. Water SA 29: 289-296.

Mashoko L, Mbohwa C, Thomas VM. 2010. LCA of the South African sugar industry. J. Environmental Planning Management 53: 793-807.

Meyer JH, Wood RA, Leibbrandt NB. 1986. Recent advances in determining the N requirement of sugarcane in the South African sugar industry. Proceedings of the South African Sugar Technologists Association 60: 205-211.

Meyer JH, Wood RA. 1994. Nitrogen management of sugarcane in South Africa. Proceedings of the Australian Society Sugar Cane Technologists 16: 93-103.

Milà I Canals L, Chenoweth J, Chapagain A, Orr S, Antón A and Clift R (2009) Assessing Freshwater Use Impacts in LCA Part I: Inventory Modelling. International Journal of Life Cycle Assessment 14: 28-42.

Mouron P, Nemecek T, Scholz RW, Weber O. 2006. Management influence on environmental impacts in an apple production system on Swiss fruit farms: Combining life cycle assessment with statistical risk assessment. Agriculture, Ecosystems and Environment 114: $311-322$.

Mudahar MS, Hignett TP. 1987. Energy requirements, technology, and resources in the fertilizer sector, in: Helsel, Z.R. (Ed.), Energy in World Agriculture Vol. 2. Elsevier, New York, USA, pp. 25-61.

Olivier F, Singels A. 2004. Survey of irrigation scheduling practices in the South African sugar industry. Proceedings of the South African Sugar Technologists Association 78: 239-244.

Parashar KS, Saraf CS, Sharma RP. 1978. Studies on the effect of soil-moisture regimes fertilizer levels on spring planted sugar cane grown pure and inter-cropped with Moong. Indian Sugar 28: 253-261

Ramjeawon T. 2004. Life Cycle Assessment of cane-sugar on the Island of Mauritius. International Journal of Life Cycle Assessment 9: 254-260.

Ramjeawon T. 2008. Life cycle assessment of electricity generation from bagasse in Mauritius. 
Journal of Cleaner Production 16: 1727-1734.

Reouf MA, Wegener MK. 2007. Environmental life cycle assessment (LCA) of sugarcane production and processing in Australia. Proceedings of the Australian Society of Sugar Cane Technologists 29: 385-400.

Renouf MA, Wegener MK, Nielsen LK. 2008. An environmental life cycle assessment comparing Australian sugarcane with US corn and UK sugar beet as producers of sugars for fermentation. Biomass and Bioenergy 32: 1144-1155.

Ricaud R. 1980. Energy input and output for sugarcane in Louisiana, in: Pimentel, D. (Ed.) Handbook of energy utilization in agriculture. CRC Press, Florida, USA, pp. 135-136.

Rochette P, Angers DA, Chantigny MH, Gasser MO, MacDonald JD, Pelster DE, Bertrand N. 2013. Ammonia Volatilization and Nitrogen Retention: How Deep to Incorporate Urea? Journal of Environmental Quality 42: 1635-1642.

South African Sugar Association Experiment Station (SASEX). 1999. Identification and Management of the Soils of the South African Sugar Industry, 3rd Edition., 174 pp.

South African Sugarcane Research Institute (SASRI). 2011. Mechanisation Report No. 2. Available from <http://www.sasa.org.za/Libraries/Publications/Mech_Report_22011.sflb.ashx>

Seabra JEA, Macedo IC, Chum HL, Faroni CE, Sarto CA. 2011. Life cycle assessment of Brazilian sugarcane products: GHG emissions and energy use. Biofuels, Bioproducts and Biorefining 5: 519-532.

Soil Classification Working Group. 1991. Soil classification - a taxonomic system for South Africa. Memoirs on the Agricultural Natural Resources of South Africa No. 15. Department of Agricultural Development, Pretoria, South Africa, pp. 138-139.

Statistics South Africa, 2005. Natural Resource Accounts: Energy accounts for South Africa, 1995-2001. Available from <http://www.statssa.gov.za/publications/DiscussEnergyAcc/DiscussEnergyAcc.pdf>

Stevens JB, Duvel GH, Steyn GJ, Marobane W. 2005. The Range, Distribution and Implementation of Irrigation Scheduling Models and Methods in South Africa. WRC Report No. 1137/1/05. Water Research Commission, Pretoria, South Africa, pp. 208.

Thompson GD. 1991. The growth of sugarcane variety N14 at Pongola. Mount Edgecombe Research Report No. 7. SASEX, South Africa. pp. 1-227.

Thorburn PJ, Biggs JS, Collins K, Probert ME. 2010. Using the APSIM model to estimate nitrous oxide emissions from diverse Australian sugarcane production systems. Agriculture, Ecosystems and Environment 136: 343-350.

Thorburn PJ, Biggs JS, Webster AJ, Biggs IM. 2011. An improved way to determine nitrogen 
fertilizer requirements of sugarcane crops to meet global environmental challenges. Plant and Soil 339: 51-67.

Thorburn PJ, Wilkinson SN. Conceptual frameworks for estimating the water quality benefits of improved agricultural management practices in large catchments. Agriculture, Ecosystems and Environment (2012) in press doi:10.1016/j.agee.2011.12.021

Tuomisto HL, Hodge ID, Riordan R, Macdonald DW. 2012. Comparing energy balances, greenhouse gas balances and biodiversity impacts of contrasting farming systems with alternative land uses. Agricultural Systems 108: 42-49.

Udo De Haes HA, Jolliet O, Finnveden G, Hauschild M, Krewitt W, Muller-Wenk R. 1999. Best available practice regarding impact categories and category indicators in life cycle assessment. International Journal of Life Cycle Assessment 4: 66-74.

Van der Laan M, Miles N, Annandale JG, du Preez CC. 2011. Identification of opportunities for improved nitrogen management in sugarcane cropping systems using the newly developed Canegro-N model. Nutrient Cycling in Agroecosystems 90: 391-404.

Van der Laan M, van Antwerpen R, Bristow KL. 2012. River water quality in the northern sugarcane producing regions of South Africa and implications for irrigation: A scoping study. Water SA 38: 87-96.

Williams AG, Audsley E, Sandars DL. 2006. Determining the Environmental Burdens and Resource Use in the Production of Agricultural and Horticultural Commodities, Main Report. Defra Research Project IS0205, Bedford, United Kingdom, pp. 84.

Wood AW, Schroeder BL, Dwyer R. 2010. Opportunities for improving the efficiency of use of nitrogen fertilizer in the Australian sugar industry. Proceedings of the Australian Society of Sugar Cane Technologists 32: 221-233. 